\title{
Mini-Grids for the Base of the Pyramid Market: A Critical Review
}

\author{
Subhes C. Bhattacharyya \\ Institute of Energy and Sustainable Development, De Montfort University, The Gateway, Leicester LE1 9BH, UK; \\ subhesb@dmu.ac.uk or Subhes_bhattacharyya@yahoo.com
}

Received: 28 February 2018; Accepted: 30 March 2018; Published: 2 April 2018

\begin{abstract}
The lack of access to electricity of more than 1.1 billion people around the world remains a major developmental challenge and Goal 7 of the Sustainable Development Goals (SDG) as well as Sustainable Energy for All (SE4ALL) have set a target of universal electrification by 2030. Various studies have identified mini-grid-based electrification as a possible solution. There is a growing body of literature available now that has explored the feasibility, practical application and policy interventions required to support mini-grids. Through a review of available literature, this paper explores whether mini-grids can be a solution for the base of the pyramid (BoP) market and the challenges faced in deploying mini-grids in such markets. Interventions to support the mini-grid deployment are also discussed. The paper finds that the mini-grids are targeting the BoP market but the business is not attractive in profitability terms and requires financial support. Lack of regulatory clarity and non-coordinated policies affect the financial viability of projects, which requires careful support. Mini-grid electrification has hardly been embedded in rural development agenda and hence they have not contributed significantly to livelihood generation. Careful realignment of policies, regulatory frameworks and support systems can better support mini-grid deployment in developing countries.
\end{abstract}

Keywords: mini-grids; BoP market; challenges; support mechanisms

\section{Introduction}

Energy access is the golden thread that joins three sustainability dimensions-economic prosperity, social development and living within environmental limits. With about 1.1 billion people lacking access to electricity and around 2.8 billion lacking access to clean cooking energies in 2016 (that is they rely on solid fuels such as coal, biomass and other traditional forms of energies that are polluting) [1], lack of energy access acts as a major hindrance to global efforts towards sustainable development. The population lacking access to electricity is mainly concentrated in Sub-Saharan Africa (588 million) and South Asia (337 million) and the rural population in general and those with low income in particular suffer the most (for example, $23 \%$ of rural habitants in sub-Saharan Africa have access to electricity as compared to $81 \%$ in developing Asia). Bhattacharyya [2] found that households with an income of less than $\$ 1000$ per person in 2005 purchasing power parity (PPP) generally lack access to clean energy, which in turn leads to poor Human Development Indicators (HDI) scores. HDI scores are positively correlated with access to electricity and access to clean cooking energies. This in turn implies that access to clean energy positively influences life expectancy at birth and mean schooling years and contributes to better human capacity development, which opens up opportunities for economic development while reducing social burdens on the environment. Households with low income spend a high share of their income on poor quality energy and depend on inefficient technologies to meet their needs. They continue to live in the vicious circle of poverty, poor health, limited human capital and 
degraded environments. Clearly, access to clean energy is a pre-requisite to sustainable development and realizing universal energy access remains a global challenge.

Despite a recent thrust on energy access with the launch of Sustainable Energy for All in 2012 and the inclusion of energy access as a global sustainable development target (in the form of Goal 7 of the Sustainable Development Goals in 2015) to be achieved by 2030, the electricity access progress has been slow. Although more than a billion people have gained access to electricity since 2000 [1], the progress has been dominated by just a few countries like India, Indonesia and other South East Asian countries. Sub-Saharan Africa, on the other hand, has seen an increase in the size of its unelectrified population over the past sixteen years (from 518 million in 2000 to 588 million in 2016) due to population growth [1]. More recently, between 2012 and 2014, an access deficit reduction of one million per year was achieved globally (the global population has increased on average 85.5 million per year whereas electricity access has increased by 86.5 million), but the regional performance remains striking. Asia-Pacific reduced the access deficit by 5 million (population growth 42 million and electricity access 47 million) during this period, whereas in sub-Saharan Africa the access gap increased by 6 million (19 million gained access against a population growth of 25 million) [3], thereby showing no real progress in the region. The spatial distribution of the incremental access gain reveals that out of about 87 million gaining electricity access between 2012 and 2014, 81 million were in urban areas and only 6million rural population gained access, which was overshadowed by rural population growth [3]. Clearly, progress with rural electrification remains unsatisfactory, particularly in sub-Saharan Africa and reaching the bottom billion requires special attention.

Stepping up electrification progress becomes crucial in order to reach the universal electrification objective by 2030. Against a target rate of increase in electrification of $0.92 \%$ per year to achieve universal electrification, only $0.19 \%$ increase was achieved between 2012 and 2014, a rate which was considerably slower than the historical annual growth rates in energy access provision $(0.51 \%$ between 1990 and 2010 and $0.69 \%$ between 2010 and 2012) [3]. Recognising that the progress in the past came from a small number of relatively better-off countries (such as India, Indonesia, Ghana, etc.) and that the future progress has to be more widespread, particularly in low-income countries, highly indebted countries and fragile states, the importance of stepping up the efforts becomes self-evident [4]. Whereas the past progress was dominated by extension of the existing grid [2], this is unlikely to be the case in the future, as grid availability is an issue in most areas and serving consumers with limited paying capacity and low demand is not a cost effective proposition for normal electric utilities. Alternative business models are emerging to serve this segment through mini-grids that carry locally generated electricity using local grids.

Over the past several years, the mini-grid business has grown significantly and they have appeared in different shapes and sizes throughout the world. IRENA indicates that more than 10,000 isolated mini-grids are operating in countries like India, Bangladesh, China, among others [5]. A study by IFC indicates that there is a potential market of $\$ 4$ billion and 28 million customers can be served using mini-grids [6]. Innovative business ideas, technology applications and practices have allowed leap-frogging the technological stages of development to offer modern services combining smart metering, payments through mobile phones and remote monitoring. Several successful examples of mini-grid based supply have been reported in the literature from around the world: Schnitzer et al. [7] provide several examples of successful micro-grids from India, Malaysia and Haiti covering private sector, government and non-profit sector interventions. The Indian examples of Husk Power System and DESI Power have also appeared in other studies $[8,9]$. The Alliance for Rural Electrification [8] provides examples of mini-grid projects from around the world. For example, Sunlabob has successfully developed a hybrid mini-grid in Lao PDR combining micro-hydro, solar $\mathrm{PV}$ and a diesel generator. A UNIDO study provides examples of successful mini-grids in six African countries (Chad, the Gambia, Guinea-Bissau, Cote-d'Ivoire, Tanzania and Zambia) and two Asian countries (India and Sri Lanka) [10]. Mini-grids have appeared in various parts of the world. However, 
despite the potential, the progress has been hindered by a range of barriers and the integration of productive use of electricity has remained limited [8].

This paper presents a critical review of available literature on mini-grid development and explores whether mini-grids can be a solution for the population at the base of the pyramid (BoP), what challenges the mini-grid business face and how such options can be supported to make the option more effective for universal electrification. The paper is organised as follows: Section 2 provides a brief description of mini-grids covering the technical features and delivery arrangements. Section 3 introduces the base of the pyramid market for electricity and confirms the role mini-grid can play in the BoP market. Section 4 provides a review of issues facing mini-grid based electricity supply for the BoP market while Section 5 focuses on support options to mitigate the challenges. Finally, concluding remarks and recommendations are provided.

\section{Brief Overview of Mini-Grids}

There is a well-developed body of academic literature on mini-grids. Bhattacharyya [2] categorised the literature in three threads, namely (1) literature on technical systems and their cost effectiveness using mainly a case study approach; (2) literature on tools and their applications; and (3) practice-oriented literature. Panos et al. [9] identified four strands of this literature, namely (1) case-oriented studies that describe the present situation in a country or region and evaluate policies and programmes; (2) technological solution-oriented studies that focus on solar PV and other renewable energies and decentralised systems such as solar home systems or micro/mini-grids; (3) national/ regional studies linking energy poverty with economic development either qualitatively or quantitatively; and (4) model-based studies that try to combine economic, technical and policy dimensions to analyse their complex interactions. Mandelli et al. [11] on the other hand reviewed more than 350 papers on the subject and classified them into five research areas: technology, models and methods, techno-economic feasibility, case studies and policy analysis. However, the term mini-grid does not mean same thing to everybody and it is important to clarify the term at the start. The purpose of this section is to provide an overview of mini-grid as a concept and to present a review of technical aspects and delivery arrangements briefly.

\subsection{Meaning of Mini-Grids}

The term mini-grid has been variously defined in the literature and is often used to contrast with the central grid. For example, Yan et al. define it broadly to include 'electrical infrastructures that serve diverse users from a single building up to an island and can interconnect and interact with the main utility grid or operate independently based on distributed energy generation' [10]. This definition does not specifically mention local generating resources and the focuses on diverse users instead. On the other hand IEA defines the term as 'a set of electricity generators and, possibly, energy storage systems interconnected to a distribution network that supplies the entire electricity demand of a localized group of customers' [12]. The possibility of grid-interactive system has not been captured here. In the Mini-Grid Policy Toolkit, a mini-grid has been defined as 'involving small-scale electricity generation (from $10 \mathrm{~kW}$ to $10 \mathrm{MW}$ ), and the distribution of electricity to a limited number of customers via a distribution grid that can operate in isolation from national electricity transmission networks and supply relatively concentrated settlements with electricity at grid quality level' [13]. However, as Knuckles commented, mini-grids are essentially distribution networks that connect generating assets to the consumers and are not businesses as such [14]. This focus on networks can be confusing as the activities involving generation, distribution and retail supply are often not fully appreciated.

In addition, other terms like micro-grid, pico-grid and nano-grid are found in the literature but there is no consensus regarding size boundaries distinguishing these terms [5]. The ranges also overlap: for example, mini-grids are often classified as systems up to a capacity of few megawatts [15], although UNFCCC allows systems up to $15 \mathrm{MW}$ (https://cdm.unfccc.int/methodologies/DB/ 9KJWQ1G0WEG6LKHX21MLPS8BQR7242). Considering that many small island systems and 
industrial projects have bigger systems, IRENA has proposed the upper limit as $100 \mathrm{MW}$ for mini-grids [5]. Micro-grids on the other hand range between $1 \mathrm{~kW}$ to $10 \mathrm{~kW}$ but Schnitzer et al. has used the term for systems up to $100 \mathrm{~kW}$ [7]. IRENA has suggested the upper limit to be extended to $100 \mathrm{~kW}$ [5]. Navigant defines a system with a capacity below $5 \mathrm{~kW}$ in an off-grid area as a nano-grid (http:/ / energyaccess.org/news/recent-news/microgrids-mini-grids-andnanogrids-an-emerging-energy-access-solution-ecosystem/)—which overlaps with the commonly used definition of micro-grids. Similarly, Brix Pedersen defines pico-grid as having a capacity between 0.5 to $5 \mathrm{~kW}$ [16] — which appears to even overlap with nano-grids defined by IRENA and Navigant. The definition issue remains problematic and it is important to arrive at a standard definition to avoid confusion. A comparison of different size ranges for different local grid systems is presented in Table 1.

Table 1. Size ranges of local grid systems. Source: Compiled by author.

\begin{tabular}{ccc}
\hline Local Grid Systems & Commonly Used Size Definitions & IRENA Proposed Categorisation [5] \\
\hline Mini-grids & 10 to few MW & $0-100 \mathrm{MW}$ \\
Micro-grids & $1-10 \mathrm{~kW}$ & $5-100 \mathrm{~kW}$ \\
Nano-grid & $0.5-1 \mathrm{~kW}$ & $0-5 \mathrm{~kW}$ \\
Pico-grid & $0-0.5 \mathrm{~kW}$ & $0-1 \mathrm{~kW}$ \\
\hline
\end{tabular}

In this paper, the term mini-grid has been used to imply the local electricity supply business instead of the networks themselves and is defined as electricity providers who supply electricity produced from local generating resources to local users using a local distribution network operating either in an isolated mode or in a grid-interactive mode. This covers the entire range of local grids shown in Table 1.

\subsection{Technical Configuration}

A mini-grid system consists of: (1) a generating capacity; (2) a power distribution network; (3) a storage unit in the form of battery banks and (4) balance-of-plant items (tracker, inverter, controller, etc.) [17]. The technical features of local grids vary in terms of generation technology used, current (AC or DC), voltage level and its interaction with the central grid. Accordingly, different categories of mini-grids are found in the literature. Mini-grids offer the flexibility of operating in an isolated mode but where the main grid is available, it can be grid connected. The generation resources can be fossil fuel based (e.g., diesel), renewable energy driven (e.g., solar PV, micro-hydro, wind) or hybrid where a combination of different resources is used (e.g., diesel-PV, PV-hydro, diesel-PV-hydro, etc.). The distribution network can carry direct current or alternating current and their voltage levels can vary.

Depending on the geographical area to be covered and expected usage, a choice is made between alternating current and direct current. Normally if the users are closely clustered around the generating source (say within a radius of $0.5 \mathrm{~km}$ ), the DC supply can be feasible but the voltage level decides how far consumers can receive a reasonable quality of supply. There is no standard voltage for a DC supply-12, 24 and $48 \mathrm{~V}$ are used, but different voltage levels can make appliance choice and interconnection of networks difficult. When a DC supply is ruled out, a standard AC supply of 220-240 V will be preferred and for higher loads, a three phase supply is commonly used [18]. Depending on the electricity generation technology used, either a back-up facility (such as a diesel generator) and/or a storage facility is required to supply electricity at night when the demand tends to peak. Because the diversity of demand is low in a local grid system, careful system design becomes important and modern demand management options through direct signals to users or load shifting can be used to ensure system reliability and management $[19,20]$. 


\subsection{Service Delivery Models}

Business models for mini-grid based electricity supply in developing countries can be classified using different criteria. Ownership is very commonly used as the basis of classification. For example, the IFC study has considered privately owned (or commercial), quasi-commercial (using corporate social responsibility or public-private partnership approach) and publicly owned (or non-commercial) services [6]. Following this line of classification, ARE has come up with four categories: community-based, private sector-based, utility-based and hybrid models [21]. Reference [13] has introduced a sub-category for the private model—regulated and unregulated environment. In the regulated environment, the regulator influences the private mini-grid behaviour whereas in the unregulated environment, the private entity carries out all activities unsupervised. ARE classification has been adopted by others (e.g., [16,22], among others). Krithika and Palit have suggested three models (private sector supply, community managed supply and village cooperatives) in their study [23]. Although Brix Pedersen claims her classification follows the actual ownership patterns and it provides a clear picture, in reality the issue is not so straightforward. The utility model can include public entities, private entities, co-operatives as well as mixed ownership through joint ventures. The community ownership is similar to common property resources-there is no clear assignment of property rights to any individuals or firms. Moreover, they may not have any legal standing due to their informal nature. The classification along ownership lines becomes fuzzy as service providers adopt different contracting and implementation arrangements.

An alternative classification of models is suggested in [24] using the nature of service provided. Three broad classes of models indicated are micro-lighting utility model, lighting-plus services and anchor load model. The micro-lighting businesses are essentially providing the basic lighting service with mobile phone charging facility to $30-50$ households, using DC or AC local grids. Solar PV is the favoured source of electricity and the service is generally available for few hours in a day. These businesses do not cater to productive loads. Mera Gaon Power in India is an example of this category. On the other hand, the lighting-plus service model extends the supply to commercial and productive activities in addition to providing basic lighting services (hence the name). Husk Power System is an example from India offering such services. In contrast, the anchor load model serves a large main commercial load alongside serving the basic needs of a settlement nearby. The bulk consumer provides the base load and supports the project viability whereas the residential load adds to the peak demand [24].

Brix Pedersen has offered an alternative categorisation based on number of consumers served and type of supply. Her categories include the following: DC village mini-grids $(0.2-5 \mathrm{~kW})$ serving up to 100 households; Anchor-Business-Community mini-grids (ABC model) (0.2-15 kW) serving an anchor load (telecom tower or lodges) and a nearby community; AC village mini-grids (1 to $300 \mathrm{~kW}$ ); large AC mini-grids serving off-grid town ( $>300 \mathrm{~kW}$ to $2 \mathrm{MW})$; grid-connected mini-grids with single wire earth return ( 0.2 to $50 \mathrm{~kW})$; large grid-connected $\mathrm{ABC}$ mini-grid (1 to $5 \mathrm{MW}$ ) and grid connection of existing mini-grids [16]. The size range used for the categorisation remains arbitrary and some are questionable as well. For example, the lower end of the $A B C$ mini-grid range appears to be very low. Similarly, the lower range of grid connected mini-grids with single wire earth return looks less plausible. The same categorisation has been adopted in [25] to suggest the following: Pico-grids including low cost DC grids ( 0.5 to $5 \mathrm{~kW}$ ); small (standardised) AC grids ( 0.2 to $15 \mathrm{~kW}$ ); ABC grids; larger AC grids (15 to $300 \mathrm{~kW}$ ) and PPA grids (above $300 \mathrm{~kW}$ to $10 \mathrm{MW}$ ).

Similarly, Reference [26] has proposed four different mini-grid types. These are: autonomous basic (AB mini-grids) for lower tier of service, autonomous full (AF mini-grids) for higher tier of service, interconnected community (IC mini-grids) and interconnected large industrial (ILI mini-grids). This report covers mini-grids from developed and developing countries and only the first two types (for lower tier and higher tier) are being used in the developing world. The other types are less prevalent at the moment but may emerge as useful option in the future. 
Mini-grid businesses involve building, owning, operating and maintaining mini-grids and Knuckles shows that businesses use a variety of value chain structuring options. In his sample, most of the businesses were responsible for construction and installation but a large portion did not operate their mini-grids. They engaged a third party or the local community to operate the systems. He concludes that the outsourcing the operation allows the businesses to reduce their operating costs and expand into other areas quickly [14]. He also found that many businesses rely on the local community or local entrepreneurs for mini-grid operation and this helps creating a shared value.

\section{Market at the Base of the Pyramid}

The interest in the base of the pyramid (BoP) consumers can be traced from the works of Prahalad and Hart [27] and Prahalad and Hammond [28] who suggested that 4 billion people living with less than $\$ 2000$ per year form the largest section of the consumer base and there are significant business opportunities for serving these consumers. However, specific features of these consumers bring significant challenges: (1) their paying capacity is low as many of them are engaged in the informal sector and in seasonal activities [29]; (2) the absence of regular income flow, lack of credit record and inability to satisfy lending requirements limit their access to traditional funding channels, which further reduces their ability to pay for traditional services [24]; (3) As a consequence of funding and income constraints, their individual demand tends to be low and the standard supply package used by service providers for other consumers may not be suitable for such markets; (4) Affordability of the service assumes significance for these consumers and Cook found that connection charges and electricity tariffs make electricity services unaffordable to the bottom-of-the-pyramid consumers [30].

While base of the pyramid consumers are found in both urban and rural areas, the business environment varies depending on the specific location. As indicated before, the electricity access situation is generally better in urban areas but people without lack of access to electricity can still be found in peri-urban locations or areas close to cities. Peri-urban areas offer locational advantages to businesses due to larger consumer base, better consumer mix (due to more likelihood of existence of commercial activities), high concentration of the consumers (which makes physical connectivity easier), and easier access to other services. On the other hand, investors face a higher risk of grid extension which can jeopardise the cost recovery of their investment.

In contrast, challenging conditions in rural areas, particularly in remote areas make BoP market riskier. Limited customer base, poor consumer mix (i.e., absence or limited share of commercial consumers), low population density (i.e., dispersed population particularly in Sub-Saharan Africa), physical remoteness and limited access to skills and human capital enhance the investment risk. On a positive note however, the risk of grid extension is likely to be low due to lower electrification priority accorded to less viable areas.

Providing services in such cases requires significant adaptation to the local context, initiatives for shaping the market and efforts for social embeddedness [31]. Following [14,31], four elements of a business model, namely value proposition for the customer, customer engagement or interface, value chain linkages and monetisation can be identified for the BoP market in the mini-grid based electrification. Push and pull factors within these elements offer different possibilities for service providers to define their businesses. Various examples can be found from the literature showing how the mini-grid businesses have tried to shape their businesses. Some such examples include the following:

(1) One successful adaptation has been to provide the service in small, affordable units [32]. Taking advantage of LED lighting, many mini-grid businesses are offering extremely low wattage level supplies (less than $5 \mathrm{~W}$ in the case of lighting only services) that were unthinkable in the era of the central grids. Even those suppliers providing lighting plus services or higher tier services are also packaging their supplies quite differently from the standard utility supplies, thereby adapting to the customer needs. 
(2) Privately-owned and commercially motivated supply providers are setting tariffs for their services considering expenditure on alternative options that compete with mini-grid based electricity. To ensure attractiveness of their supply, the tariff is being set lower than expenses on monthly kerosene consumption or payments to diesel generator-based supplies.

(3) Businesses are using innovative billing and collection systems using smart meters, prepaid meters, and mobile payment systems to improve revenue collection efficiency and reduce defaults.

(4) To mitigate business environment-related risks, innovative contractual arrangements are being used: for example, joint liability groups have been used to manage credit and payment risks. Similarly, flexible bill collection approaches (daily or weekly collection) have tried to align billing cycle to consumer characteristics [33].

(5) To support financing their electricity access, micro-credit facilities are being used. The supply provider working with the consumers organise such credits so that the market is created. The example of Grameen Bank in Bangladesh appears in the literature widely but such credit systems are being used in other countries as well [31]. However, Reference [33] remarks that poor consumers are paying high interest rates ( 2 to $3 \%$ per month) for the credit remains a major issue.

The above discussion answers our first question: mini-grid based electricity supply is reaching the BoP market and offering basic level of services. However, despite the efforts to adapt to the BoP market environment, the mini-grid based electricity provision faces significant challenges. We turn to these issues in the next section.

\section{Challenges Facing Mini-Grid Based Electricity Supply in BoP Markets}

This section focuses on three main challenges: weak regulatory and policy environment, business viability and affordability challenges, and financing issues.

Manetsgruber et al. [34] undertook a stakeholder consultation to identify the risks to mini-grids. Figure 1 shows the main barriers identified by the study. Weak enabling environment (regulatory and policy frameworks) emerges as the main challenge, followed closely by lack of appropriate fund structure, inadequate funding ticket size and lack of background knowledge of financiers.

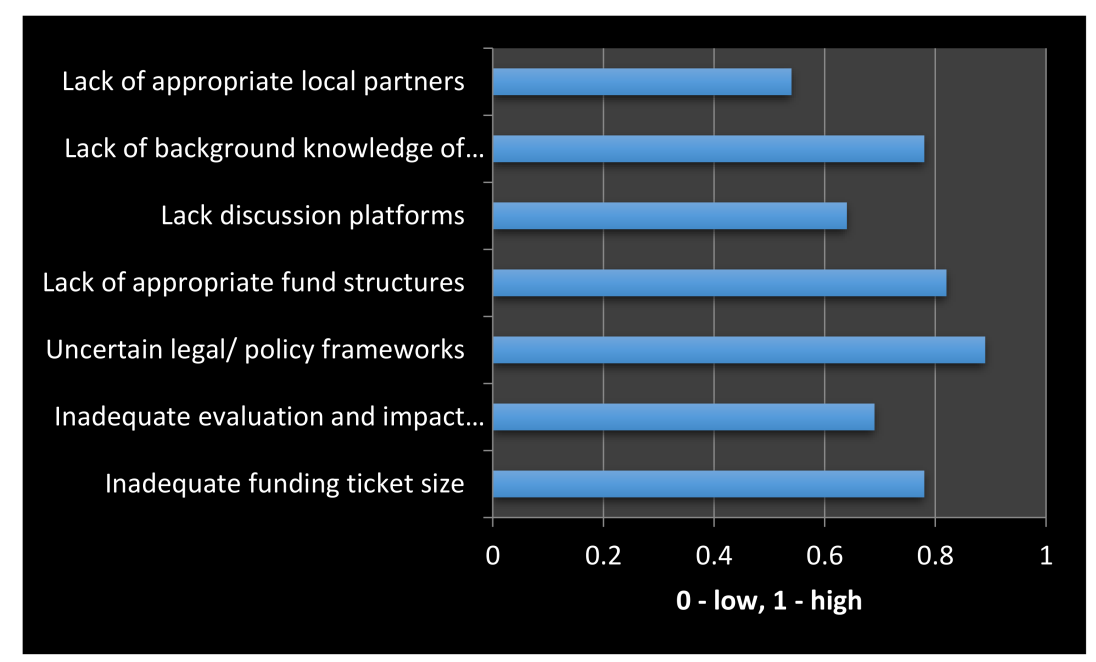

Figure 1. Barriers to mini-grid development. Source: [34].

\subsection{Regulatory and Policy Environment}

In order to ensure electrification of BoP markets, a properly defined business environment is an essential requirement, particularly when the private sector participation is aimed at to accelerate the electrification process. A mini-grid based supply is a mini utility business involving generation, distribution and retail supply activities and the business environment is influenced by institutional 
endowments and institutional arrangements. The local policy and business environment influence the investment decisions but the literature has paid less attention to support mechanisms to promote mini-grid activities. While [35] has devoted a lot of attention to developing the independent power producer model for rural electrification where the generator enters into a contractual arrangement with the utility company for sale of power or sales to the bulk consumers through a contract, the mini-grid development in most countries is not following the functional separation model of business activities. Instead, a vertically integrated approach covering generation, distribution and retail supply is being used by the mini-grid businesses. In what follows, a functionally integrated business model is being considered.

Based on the available literature, regulatory weaknesses in a number of areas can be identified $[24,36]$ :

(1) Coverage: The service area of a mini-grid based supply may not be clearly demarcated avoiding overlaps with the service area of the central grid utility. In many countries, the national electricity company or a distribution licensee may already have the jurisdiction over the area and unless a service area for the mini-grid is carved out legally, the legal basis for the mini-grid can be problematic. Moreover, this leads to the other issue, which [37] calls the gateway problem-the threat of grid extension by the central grid. In the absence of clarity over jurisdiction of service area, the threat of grid extension acts as a major deterrent for private sector investment in mini-grids. The possibility of an aggressive grid extension effort by the incumbent and the potential for stranded mini-grid assets in the absence of a defined exit mechanism is a major investment risk. This can also be an issue when two or more mini-grid operators appear in the same area-which can duplicate the system and lead to non-optimal resource use. Accordingly, a non-overlapping service area is essential.

(2) Permission for doing business: Electricity generation and supply is a regulated activity in most countries around the world but the legal provisions do not often recognise the decentralised models of supply. This may be due to old legal provisions or may be deliberately left out to avoid overburdening of the regulatory system. In the absence of a proper approval system, legitimising mini-grid businesses may be difficult. Ambiguity in the legal area breeds confusion and alternative interpretations cause business uncertainty, which reduces attractiveness of the market to potential investors. A simple, transparent and low cost approval system is a must [38].

(3) Eligibility requirements: Being an emerging opportunity, many new entrants are entering the business but unless they meet certain capacity requirements (in technical, financial and organisational terms), the development of the business is likely to be affected through reduced credibility, loss of trust and perhaps misuse of resources. Lack of clear eligibility requirements opens the door to everyone, making it difficult for the serious businesses to establish themselves.

(4) Conditions of supply: A business engaged in electricity supply has to satisfy a certain conditions. For example, the supply has to be safe and secure. The service has to offer non-discriminatory supply to all eligible consumers. Similarly, conditions for connection/disconnection, prevention of market abuse, minimum performance targets, etc. are other conditions normally applied. Lack of clarity about business engagement and expectations can reduce effectiveness of the businesses [35].

(5) Tariff-related issues: Any confusion regarding tariffs or any potential for disagreement in this area can be fatal for the viability of a mini-grid business. While businesses aim for cost recovery, high cost of supply can limit the consumer base due to affordability issues. On the other hand price parity with the central grid or a uniform tariff for all mini-grids can create viability issues for the investors [13]. Balancing this trade-off is a demanding challenge as favouring one will affect the other party adversely. For example, in the Uttar Pradesh Mini-grid Policy in India, if the mini-grid developer adopts the capital subsidy route where $30 \%$ of the capital cost will be subsidised, then the tariff has been prescribed for the basic service level (serving a load of $100 \mathrm{~W}$ for $8 \mathrm{~h}$ per day). The prescribed tariff aims parity with grid-based supply but this is unlikely to make the mini-grid business viable [37]. An overly prescriptive approach is likely to be less 
acceptable to the investors while a very lenient approach can lead to abuse of market power by the supplier. Negotiated solutions are allowed in some countries but as the supplier tends to have a higher bargaining power, the decision-making can be highly influenced by them.

The regulatory needs of mini-grid investors can be summarised under four headings: technical, commercial, economic and administrative [8]. The technical operating standards, safety, reliability and quality standards would come under the technical head. Tariff and conditions of supply that affect the profitability of the business would come under the commercial aspect. The subsidy and other support mechanisms to assist economic viability of mini-grid businesses would fall under the economic head. Finally, the administrative procedures for setting up and doing business will fall under the administrative dimension.

In addition to a stable regulatory environment, the business environment also needs supportive policies to facilitate the development of a thriving business. A range of policies at the national and local levels influences the investments in mini-grids. For example, the fiscal policies directly affect the costs and incomes of a project. Being modern technologies, many countries rely on imports of project components and the import duty can directly affect the capital cost of a project significantly. It is reported that phasing-in of value added tax on solar panels in Kenya has affected the profit margins of mini-grid operators [39]. Similarly, the subsidy policy particularly on electricity supply from the central grid and on fossil fuels that compete with mini-grid electricity affects the project viability. While consumers of central grid electricity benefit from subsidy and cross-subsidies, the mini-grids are generally excluded from this support [40], thereby creating a disconnected policy framework. Financial policies particularly those relating to credits and debt financing (including commercial loans) are relevant for the mini-grid businesses. As discussed below, financial issues remain a major constraint for mini-grid businesses around the world.

Another area where policy integration is lacking is the use of mini-grid based electricity for productive purposes and income generation. Although significant potential exists for integration of livelihood activities, mini-grids have hardly exploited such potentials and very limited income generation activities have been realised in practice [41]. Lack of efforts to embed rural electrification efforts in the local development agenda is a manifestation of the absence of a whole systems approach to policy-making.

Evidently, the more prepared a country is in terms of its business environment, more attractive it will be to investors. An international comparison of regulatory indicator for sustainable energy by the World Bank [42] has ranked countries for regulatory environment for energy access, renewable energy and energy efficiency. The energy access component has been evaluated using 8 sub-indicators, each scored out of 100. The overall score is obtained by averaging the sub-indicators. For the energy access component India, with 84 points, tops the list (see Table 2). At the component level, green traffic lights for all categories also confirm India's position compared to other countries. In fact, India is the only country in the list with all green lights (see Table 2). It confirms that India has put in place all relevant pieces to create the enabling environment. Kenya and the Philippines follow closely with 82 points but Kenya has two scores in the yellow range whereas Philippines has one yellow score. On the other hand, countries at the bottom of the list are located in Sub-Saharan Africa and most of them do not have suitable regulatory environment in place to support energy access. 
Table 2. Regulatory indicator for energy access in selected countries.

\begin{tabular}{|c|c|c|c|c|c|c|c|c|c|}
\hline Country & Total & $\begin{array}{l}\text { Electrification } \\
\text { Plan }\end{array}$ & Scope of Plan & $\begin{array}{l}\text { Grid Electrification } \\
\text { Framework }\end{array}$ & $\begin{array}{l}\text { Framework for } \\
\text { Mini-Grids }\end{array}$ & $\begin{array}{l}\text { Framework for Stand } \\
\text { Alone Systems }\end{array}$ & Affordability & $\begin{array}{c}\text { Utility } \\
\text { Transparency }\end{array}$ & $\begin{array}{l}\text { Utility Credit } \\
\text { Worthiness }\end{array}$ \\
\hline \multicolumn{10}{|c|}{ Top Ranking Countries } \\
\hline India & 84 & 80 & 75 & 100 & 77 & 69 & 100 & 96 & 76 \\
\hline Kenya & 82 & 100 & 50 & 67 & 66 & 93 & 100 & 96 & 86 \\
\hline Philippines & 82 & 100 & 75 & 67 & 85 & 62 & 100 & 87 & 82 \\
\hline Uganda & 78 & 100 & 63 & 67 & 64 & 93 & 100 & 79 & 59 \\
\hline Tanzania & 75 & 100 & 50 & 100 & 96 & 73 & 100 & 83 & 0 \\
\hline Bangladesh & 68 & 80 & 25 & 33 & 74 & 80 & 100 & 100 & 54 \\
\hline \multicolumn{10}{|c|}{ Bottom Ranking Countries } \\
\hline Sierra Leone & 17 & 0 & 0 & 0 & 35 & 40 & 50 & 8 & 0 \\
\hline Chad & 14 & 0 & 0 & 17 & 30 & 11 & 50 & 4 & 0 \\
\hline Haiti & 13 & 0 & 0 & 0 & 43 & 11 & 50 & 0 & 0 \\
\hline Central African Republic & 11 & 0 & 0 & 0 & 10 & 11 & 0 & 17 & 50 \\
\hline Somalia & 3 & 0 & 0 & 0 & 5 & 22 & 0 & 0 & 0 \\
\hline
\end{tabular}

Legend: red $\leq 33$; yellow $33<x<67$, green $\geq 67$. Data source: [42]. 
In terms of framework for mini-grids, only 14 countries are in the red, while 29 countries are in the yellow category and 12 countries are in green area. This suggests most of the countries have made some progress in respect of mini-grids but there is still some distance to cover to reach a mini-grid friendly regulatory environment in all countries.

A similar picture arises from the global off-grid business indicator (OBIN) presented by [43]. It identifies India as the largest global market for off-grid business, with a market potential of $\$ 27$ billion for rural electrification and above $\$ 5$ billion for kerosene replacement. The global off-grid market has been estimated at $\$ 136$ billion, which is almost equally split between Asia and Africa. The report then classifies the countries in different regions in five categories in terms of their business environment. Most of the countries fall in the average or below average categories but more African countries appear in the below average category than in Asia. Access to finance, corruption and inadequate infrastructure are identified as major barriers in Africa whereas corruption, inefficient bureaucracy and access to finance are barriers hindering off-grid markets in Asia.

IRENA [44] through a survey of stakeholders in South Asia and sub-Saharan Africa identified the barriers to mini-grid development (see Figure 2). The stakeholders identified policy uncertainty as the most important challenge. Lack of clarity and information about the electrification plan of a village and lack of information sharing/guarantee mechanism to ensure that grid connectivity will not materialise within a certain period is a major barrier for investors. Unclear regulatory rules particularly related to grid connectivity and asset obsolescence are related issues affecting the investment risk profile.

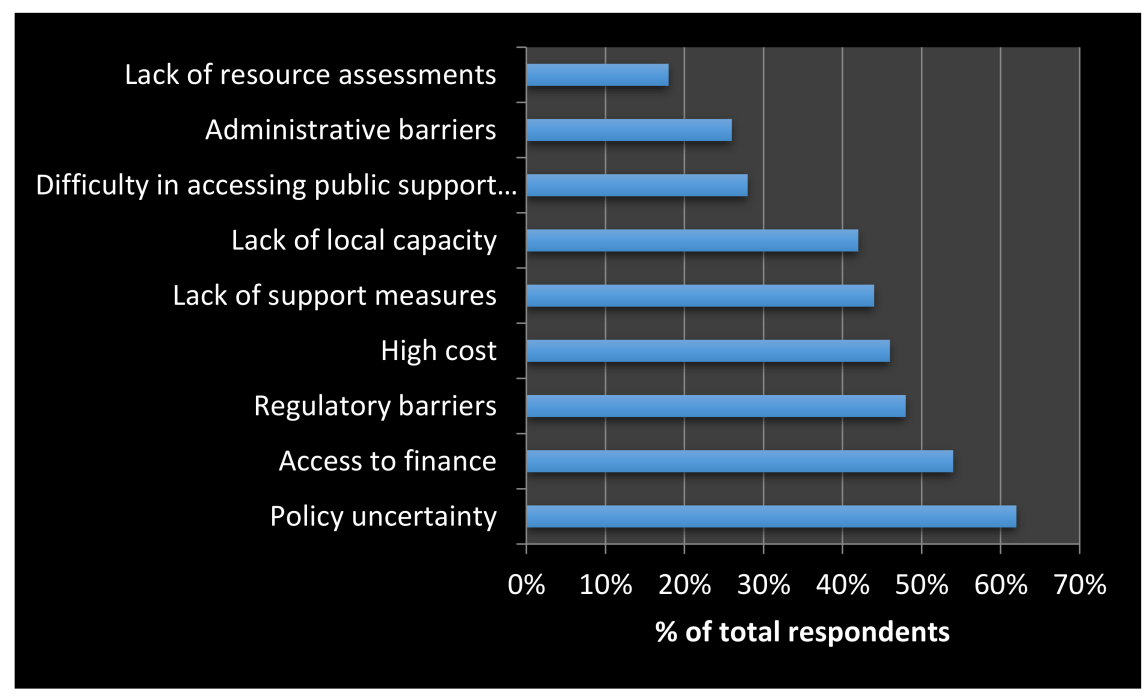

Figure 2. Barriers to mini-grid development. Source: [44].

The long-term sustainability of many off-grid projects is low due to failure to address the socio-cultural issues of the target communities and unresponsive policies arising from failure to incorporate user perspectives [45]. Creating an enabling policy environment for off-grid supply, particularly for mini-grids is an important issue, for which Bhattacharyya and Palit [33] offer a set of guidance to create a win-win situation for all stakeholders.

\subsection{Viability and Affordability Issues}

Various studies have considered the viability of different mini-grid projects and they can be grouped under three main categories: (1) those evaluating the generic case of cost of electricity supply of individual or hybrid combination of generating technologies using levelised cost of supply or similar approaches; (2) techno-economic analysis of real or hypothetical projects using a simulation tool such as Hybrid Optimisation Model for Electric Renewables (HOMER); and (3) case studies of specific projects. Table 3 provides a selected list of studies under each category. It should be noted that 
there are overlaps in the above categorisation as it is not always possible to fit a study into a specific category. Techno-economic studies are often case study based but because they have used a simulation or feasibility analysis approach, they are placed in the techno-economic category.

Table 3. Selected studies on viability of mini-grid based electricity supply.

\begin{tabular}{ccc}
\hline Cost of Supply Studies & Techno-Economic Studies & Case Studies \\
\hline$[20] ;[46-52]$. & {$[53-63]$.} & {$[7],[64-66]$.} \\
\hline
\end{tabular}

Most of the studies on mini-grid project viability mention the advantage arising from the declining costs of solar PV technology but even considering the significant reduction in capital costs, the cost of electricity supply from mini-grid per unit (i.e., per $\mathrm{kWh}$ ) remains relatively high. Their cost varies over a significant range depending on the technology used: generally diesel-based supply tends to cost the most whereas biogasification plants and micro-hydro systems tend to offer the lowest costs, with solar PV and hybrid options somewhere in between. For example, Reference [37] estimated the following levelised costs of supply for the Indian case: $\$ 0.95 / \mathrm{kWh}$ for household level diesel generators, $\$ 0.94 / \mathrm{kWh}$ for kerosene lanterns, $\$ 0.57 / \mathrm{kWh}$ for diesel mini-grids, $\$ 0.54 / \mathrm{kWh}$ for solar PV-diesel hybrid systems, and $\$ 0.38 / \mathrm{kWh}$ for solar PV-battery mini-grids. As indicated in [26], the unsubsidised cost for the basic service in 2015 ranges between 0.47 to $0.71 \mathrm{USD} / \mathrm{kWh}$ whereas for full service the cost ranges between 0.61 to $0.92 \mathrm{USD} / \mathrm{kWh}$. While the cost is likely to decline significantly in the future, the full cost at present remains very high by any standard. Zubi et al. confirm that affordability of solar PV remains an issue in regions lacking electricity access but suggest that strategies like high value applications, energy efficient solutions (such as LED lamps) and cost reduction could improve the attractiveness of the technology [67].

Moreover, as the mini-grid supply is often unfavourably compared with the tariff charged by the grid supply (even though grid is unlikely to reach these locations), the acceptance of high cost of supply by the BoP consumers becomes an issue. The innovative tariffs used by the suppliers and the benchmarking of tariffs with current fuel expenditure of the potential users circumvent the issue of direct tariff comparisons with the grid supply. However, where the alternative source of energy is highly subsidised and the grid electricity tariff is kept artificially low, BoP consumers may not accept high cost mini-grid supplies. Further, the question of social justice arises: why the poor in remote and rural locations would have to pay exorbitantly high price for accessing electricity? This gains further legitimacy where the grid has the opportunity to average out the cost and benefits from cross-subsidies and subventions. Due to adverse consumer mix, cross-subsidies are practically impossible for a small local system and operating subsidies generally do not flow to mini-grids. This discrimination affects the BoP market development for electricity.

Clearly, unsubsidised supply is less attractive to the BoP consumers [68] although willingness to pay studies suggest that consumers are generally not adverse to paying higher charges for a reliable supply. For example, Reference [32] finds BoP consumers in Bangladesh are willing to pay $\$ 0.43 / \mathrm{kWh}$ for electricity from a renewable mini-grid whereas Reference [69] finds that users of mini-grid supply in India value local supply much higher than the central grid based supply and are willing to pay about INR $70 / \mathrm{kWh}$ (or about $\$ 1.05 / \mathrm{kWh}$ ). However, the willingness-to-pay estimates vary greatly and exploiting the locational disadvantage of the consumers to charge a high tariff cannot be a rationale objective.

To overcome the financial viability challenge, governments and donor agencies have provided financial support to investors to reduce the capital cost burden. As demonstrated in [50], capital cost subsidy is insufficient for achieving grid-parity price for mini-grids and the operating cost subsidy imposes significant recurring burden on government's budget, particularly when the plant size increases and the number of such plants multiply. However, mini-grids offer a window of opportunity to rationalise fossil fuel subsidies and use the budget so saved to promote renewable energy mini-grids. 
A study by Reference [70] has provided the comparative strengths and weaknesses of three categories of existing mini-grid initiatives: those supported by financers and donors; those promoted by supply chain entities, and those by NGOs/communities. Table 4 compares some technical characteristics that affect viability of mini-grids.

Table 4. Comparative position of characteristics affecting technical capability. Source: [70].

\begin{tabular}{|c|c|c|c|}
\hline Characteristics & $\begin{array}{l}\text { Mini-Grids Supported } \\
\text { by Financiers }\end{array}$ & $\begin{array}{l}\text { Mini-Grids Developed by } \\
\text { Supply Chain Entities }\end{array}$ & $\begin{array}{l}\text { NGO/Community } \\
\text { Supported Mini-Grids }\end{array}$ \\
\hline $\begin{array}{l}\text { Capacity to aggregate demand to achieve } \\
\text { financial viability }\end{array}$ & Low & Low & Moderate \\
\hline $\begin{array}{l}\text { Flexibility to tailor technical solutions to } \\
\text { variable demand and environmental conditions }\end{array}$ & Low/NA & Moderate & High \\
\hline $\begin{array}{l}\text { Flexibility to adapt programmes across } \\
\text { geographic and environmental conditions and } \\
\text { different consumer behaviour }\end{array}$ & Low/NA & Moderate & High \\
\hline $\begin{array}{l}\text { Capability to manage O\&M risks and optimise } \\
\text { O\&M service delivery }\end{array}$ & Low & High & Low \\
\hline Ability to optimise supply chain & Low & High & Low \\
\hline $\begin{array}{l}\text { Technical capacity to deliver high quality } \\
\text { service throughout the project life }\end{array}$ & Low & High & Low \\
\hline $\begin{array}{l}\text { Capacity to aggregate demand to reduce } \\
\text { administration costs significantly }\end{array}$ & Low & Moderate & Moderate \\
\hline
\end{tabular}

\subsection{Financing Challenges}

To achieve the target of universal electrification by 2030, it is estimated that $\$ 52$ billion annual investment will be required for the remaining period and about $50 \%$ of this investment will go to mini-grids and a majority of the investment will be required in sub-Saharan Africa [1]. Clearly, financing the universal electrification projects remains a big challenge. There are different perspectives of the problem: for financial institutions and lending agencies, the transaction volume is too low to be cost effective and many large entities are not interested in this market even if some sort of project aggregation is undertaken. Moreover, the business is not understood by the financial sector and is considered to be risky due to lack of bankable revenues streams through sales agreements or power purchase agreements. The mini-grid sector is an infrastructure development activity but unfamiliarity with the risks of this sector makes lenders reluctant to engage with the sector.

To ensure fund flow and increase private sector engagement, the risks have to be mitigated. It suggests that the mini-grid market could benefit from a Risk Sharing Facility. Similarly, a co-developer fund where funds from several sources are raised and which takes the risk to a greater extent can be beneficial for the sector.

On the other hand, the investors need access to suitable funding to reduce their cost of supply and make the investment viable. Depending on the ownership of the mini-grid project, the access to finance can vary. The private investor may have easier access to the capital market because of its previous track record and its ability to use its balance sheet for securing loans. In contrast, a community-based organisation created for the purpose of developing or operating a mini-grid may not have any formal standing as a corporate body. Absence of past credit record for such organisations, limited own-funding ability and limited security for guarantee purposes make borrowing difficult and costly. As most lenders require at least 20 to $30 \%$ of the cost as down payment, mobilizing such funds locally can become a Herculean task at the village level, thereby creating hurdles for their integration with the mainstream and making their long-term viability difficult [24]. A study by Reference [71] suggests that the 'bridging capital' is missing in the nascent mini-grid sector and the tenure of debt capital is too short for an emerging market.

On a related side, one of the hurdles faced by BoP consumers is the ability to pay for connection charges [30]. Unaffordable charges deter consumers, which in turn lower the demand for electricity for the mini-grid investor. Similarly, electricity demand, being a derived demand, can only arise when 
consumers buy appliances but the capital-intensive nature of appliances makes it impossible for BoP consumers to buy them. Suitable micro-financing facilities to scale up the energy ladder are required but they may not be available in many places.

IRENA [44] reported the stakeholder perception about the main reasons behind the financial challenge (See Figure 3). The high-risk perception about the sector is the main barrier. The lending term comes next, which is followed by the general lack of understanding of the financial institutions about the sector.

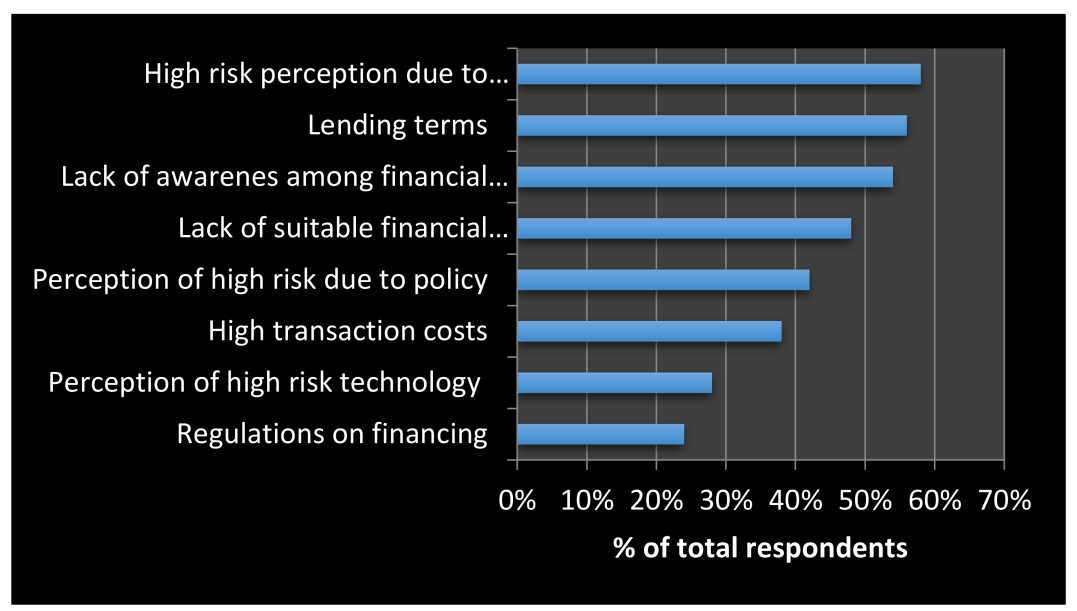

Figure 3. Perception about the financial challenge. Source: [44].

As small companies are often engaged in the mini-grid sector due to small size of the project, the financial needs are somewhat different and the risk of failure can be high due to low margin of their businesses. IRENA [44] also indicates that traditional project debt financing or infrastructure financing models do not work for mini-grids as the sector is not mature yet and the commercial banking sector does not understands the risks in the business. The development finance institutions have a role here to bridge the finance gaps and support risk mitigation. There is the need for patient capital.

ADB [70] compared finance-related positions of different mini-grids (see Table 5). NGO or community managed mini-grids appear to be in a disadvantageous position and supply chain entities also do not perform well in terms of their financial capabilities. Only financial institution supported mini-grids appear to have the requisite financial knowledge.

Table 5. Mapping of comparative finance-related strengths and weaknesses of mini-grid types. Source: [70].

\begin{tabular}{lccc}
\hline \multicolumn{1}{c}{ Characteristics } & $\begin{array}{c}\text { Mini-Grids Supported } \\
\text { by Financiers }\end{array}$ & $\begin{array}{c}\text { Mini-Grids Developed by } \\
\text { Supply Chain Entities }\end{array}$ & $\begin{array}{c}\text { NGO/Community } \\
\text { Supported Mini-Grids }\end{array}$ \\
\hline Knowledge of fund creation & High & Moderate & Low \\
\hline $\begin{array}{l}\text { Ability to optimise finance structure } \\
\text { to specific local contexts }\end{array}$ & High & Low & Low \\
\hline $\begin{array}{l}\text { Ability to mobilise finances to scale at } \\
\text { low transaction costs }\end{array}$ & High & Low & Low \\
\hline $\begin{array}{l}\text { Ability to access support finance to } \\
\text { guarantee high risk consumer base }\end{array}$ & High & Low & High \\
\hline
\end{tabular}

\subsection{Other Issues}

In addition to the above, the mini-grid business faces several other challenges. Technical capacity is an essential requirement to ensure effective design, operation and maintenance required for a reliable supply [8]. If the capacity is designed without any room for demand growth, the reliability of supply can become a problem. Similarly, the technology choice and proper back-up arrangements are important to avoid consumer dissatisfaction [11]. However, over-design to allow room for demand 
growth can be costly and trade-off is required. Moreover, such decisions should be considered at the design stage but given their inter-relatedness with other dimensions, a systematic tool for decision analysis as suggested by [72-74] can be helpful for such complex decisions. The supply chain required for the mini-grid deployment is not well developed in many countries and there is little standardisation in terms of design, components used and practices. As a result, a range of systems is being used and it makes inventory management, repairs and system integration more difficult. Power demand uncertainty, power quality risk, equipment failure risk, hardware compatibility, and inadequate storage are some other technical issues identified by Reference [66].

Other issues include social, sustainability, organisational and safety issues. For example, Reference [45] indicates inadequate focus on social embeddedness of mini-grids through stakeholder buy-in. Similar views are also expressed by $[13,67]$. Sustainability issues of mini-grids have also been raised in the literature-particularly those relying on diesel generation and subsidies $[2,66]$.

Regarding barriers to scaling-up of mini-grids, Manetsgruber et al. [34] indicated that lack of access to finance is the main challenge (Figure 4). Low profit margin, limited ability to pay and lack of qualified staff emerge as other main barriers.

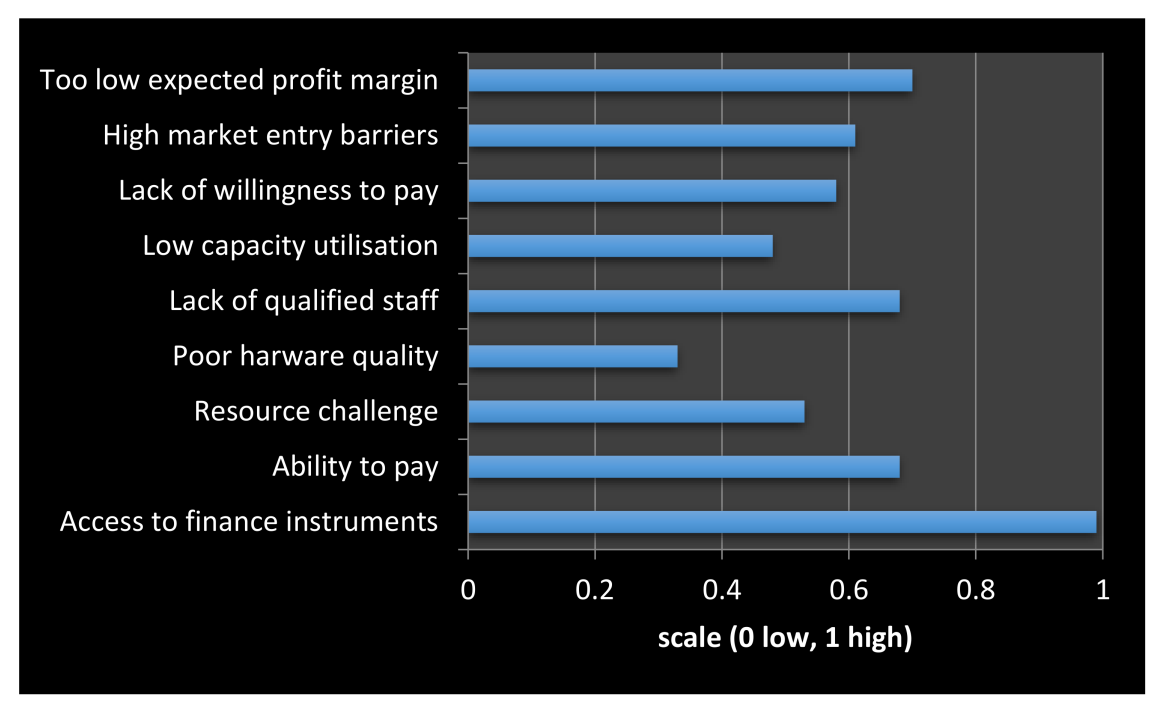

Figure 4. Barriers to scaling-up of mini-grids. Source: [34].

The report identifies three main categories of risks, namely political risk, payment risk and resource price variability risk. The project viability and return on the investment can suffer due to political changes in a country or political instability. The revenue stream of a project also suffers adversely when a purchaser or off-taker stops paying or reduces paying for the services. The price variability of key input resources (fuel mainly) due to changes in the market conditions also adversely affects a project. They suggest that a standardised risk management procedure would be useful but many mini-grid project developers are not aware of such mechanisms and would need capacity building in this area.

Although a sizeable market for mini-grids can be identified to meet the BoP needs, the existence of barriers and challenges suggests that the markets are unlikely to develop on its own. To mitigate the market failure, there is a need for strategic government interventions to support the market. The next section discusses this.

\section{Supports and Interventions for Mini-Grid Business Development}

Various studies have provided lessons from their analysis and offered suggestions for interventions. These recommendations range from generic policy and support advices to specific issues such financial or technical or regulatory interventions. Irena [44] reports the preferred actions 
for government intervention in the sector (see Figure 5). It indicates that off-grid policy strengthening and long-term rural electrification strategy appear as the most important areas. Supporting regulations on financing and supportive fiscal measures are the other two important factors identified by them. Capacity building and removal of administrative barriers received relatively lower support while stringent quality control measures received the least support.

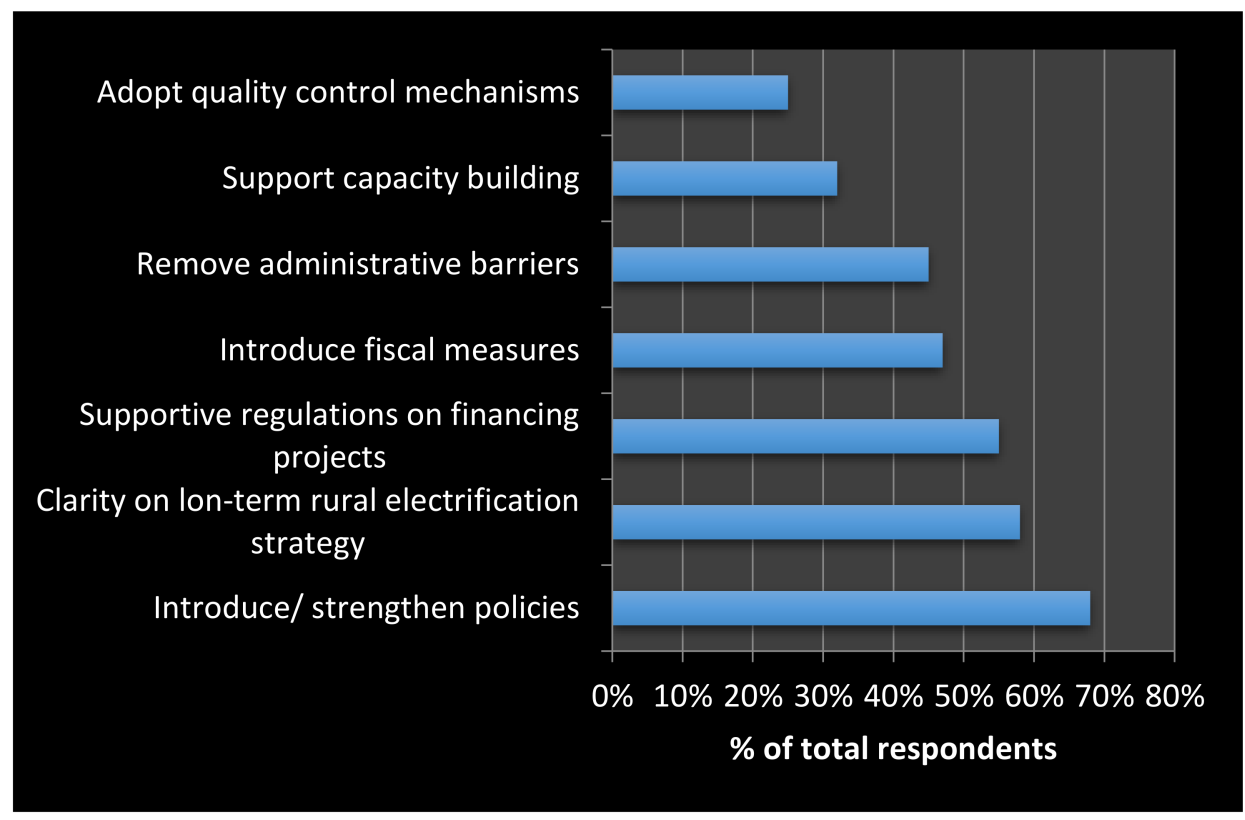

Figure 5. Areas for government intervention in off-grid sector. Source: [44].

Given the conditions of BoP markets are highly context specific and because technology choice, social acceptance, ownership patterns and economic linkages are context dependent, Bhattacharyya et al. suggest that any successful intervention strategy for mini-grids has to be embedded in economic linkages considering the strengths and ability of community structures [75]. Accordingly, they identify four cases shown in Table 6-each of which will require a varying set of support arrangements. It is perhaps possible to link the four categories to the regulatory indicator study mentioned previously [42] and use a similar colour code to identify different categories of locations for intervention strategies. Communities with poor economic linkages and poor community strength would need greater handholding than those areas where the community is thriving and the economic activities are already taking shape. Such a classification of potential markets will be useful to different stakeholders: investors can identify areas for their future investments, policymakers can better target their policies and progress monitoring of development will be easier.

Table 6. Possible local context conditions for intervention design. Source: Based on [75].

\begin{tabular}{cll}
\hline Community Type & \multicolumn{1}{c}{ Strong Economic Linkages } & \multicolumn{1}{c}{ Poor Economic Linkages } \\
\hline Vibrant community & $\begin{array}{l}\text { Vibrant community with strong } \\
\text { economic linkages }\end{array}$ & $\begin{array}{l}\text { Vibrant community but poor economic } \\
\text { linkages }\end{array}$ \\
\hline Poor community strength & $\begin{array}{l}\text { Poor community structure/ strength } \\
\text { but strong economic linkages }\end{array}$ & $\begin{array}{l}\text { Poor community strength and poor } \\
\text { economic linkages }\end{array}$ \\
\hline
\end{tabular}

From Table 6, one area for possible government intervention becomes clear: identification of potential markets and information about their local contexts. This is a time-consuming and resource-intensive process and the government is in a better position to share such information to help mini-grid sector development in any country. 
Following from the above spatial characterisation of potential BoP markets, a natural candidate for intervention is to tailor financial support instruments recognising the degree of difficulty of developing a viable mini-grid business. Instead of a standard one-size-fits-all policy and financial support mechanism, policies need to attract investors and social enterpreneurs to challenging market contexts so that no one is left behind. The concept of viability gap funding has been suggested in the literature for this purpose (see for example [69] particularly in the case public-private partnership projects. Here the difference between the revenue and the costs for the supply is paid to the investor to ensure financial viability. This is a subsidy mechanism but it can be tailored to meet individual cases, although there can be significant administrative costs particularly in the case of small projects). Other financial support arrangements such as making credit lines available through rural banks, agricultural banks and through micro-credit facilities for consumers can also be beneficial for the development of the sector.

A third area of intervention could be embedding the mini-grid development in local development planning activity so that the productive use of energy and general electrification can be harmonised. Developing commercial activities can be a different project in itself and the investor may not have appetite for such additional non-core activities. Such an integration of livelihood opportunities requires the project developer to get involved with the local community to develop the opportunities and can be a costly and time-consuming activity. The developer may not have skills in such activities and often this is beyond their core competence. This can deter investors. Local government engagement can avoid isolated development of mini-grids without any link to the local development agenda. Through a coordinated effort, the overall objective of sustainable development can be better achieved.

However, focusing at the local level will not be enough to address the challenges of mini-grid development and would have to be supplemented by national level frameworks and policies. Possible macro-level interventions include the following:

(1) Giving a legal status to mini-grid business: defining the mini-grid space legally in the electricity acts and clarifying the scope of the business is essential to create the activity;

(2) Defining the regulatory framework: formulating appropriate regulatory arrangements for managing mini-grids, defining standards of service for mini-grids, and policies for entry/ exit and coordination of grid and mini-grid based electrification are some aspects of regulatory and electricity planning that are essential.

(3) Tariff and financial support policy: A generic framework for tariff and subsidy for mini-grids and its delivery mechanism can bring clarity to the business activity.

(4) Fiscal incentives: Tax breaks and tax holidays for businesses, waiver of import duties and reductions in value added tax or service tax are possible ways of incentivising the activities.

(5) Risk mitigation measures: Because mini-grids are considered as high risk low return investment propositions, risk mitigation measures to minimise impacts on the investors can be designed at the national level.

(6) Consumer support mechanisms: Arrangements for supporting the BoP consumers to enable them access electricity will also be important.

Combining macro and local level supports will be essential to deliver the mini-grids at the BoP market.

\section{Conclusions}

The base of the pyramid offers a large potential market for electrification through mini-grids and the initiatives for universal electrification have brought opportunities to reach these markets. The market is widely spread across sub-Saharan Africa and South Asian countries, particularly in the rural areas. Technological innovation is allowing emergence of new business approaches and models and mini-grid businesses are adapting and aligning their deliveries to meet the specific characteristics of the BoP market. However, the viability of the business remains an issue due to 
high risks involved in the BoP market, fragmented nature of the market and hence small scale of the businesses. Weak regulatory arrangement and policy frameworks increase the business risk, which in turn results in high cost of capital and poor profitability of the business. Businesses offering the basic level of service are breaking-even through innovative tariff and cost-cutting approaches but to make the businesses profitable, the need for financial support cannot be ignored. Given the cost profile varies depending on the technology choice and local context of the business, a standard one-size-fits-all policy does not serve the purpose and a more flexible approach whereby a macro-level policy supplemented by a local level contextualised policy would be required. Lack of financial viability has also implied that mini-grid projects have hardly exploited the potential economic linkage for livelihood generation and sustainable development of local communities. A lack of integration of mini-grid development plan with local development plan and the absence of policy coordination at different levels has resulted in this failure. Consequently, sustainable rural development through mini-grid based electrification will require close coordination of policies and planning activities.

Conflicts of Interest: The authors declare no conflict of interest.

\section{References}

1. IEA. Energy Access Outlook, Special Report of World Energy Outlook 2017; International Energy Agency: Paris, France, 2017.

2. Bhattacharyya, S. Energy access programmes and sustainable development: A critical review and analysis. Energy Sustain. Dev. 2012, 16, 260-271. [CrossRef]

3. IEA and the World Bank. Sustainable Energy for All-Global Tracking Framwork: Progress toward Sustainable Energy; The World Bank: Washington, DC, USA, 2017.

4. World Bank. State of Electricity Access Report; The World Bank: Washington, DC, USA, 2017.

5. IRENA. Off-grid Renewable Energy Systems: Status and Methodological Issues; International Renewable Energy Agency: Abu Dhabi, UAE, 2015.

6. IFC. From Gap to Opportunity: Business Models for Scaling up Energy Access; International Finance Corporation: Washington, DC, USA, 2012.

7. Schnitzer, D.; Lounsbury, D.D.S.; Carvallo, J.; Deshmukh, R.; Apt, J.; Kammen, D. Microgrids for Rural Electrification: A Critical Review of Best Practices on Seven Case Studies; United Nations Foundation: Washington, DC, USA, 2014.

8. Draeck, M.; Kottasz, E. Renewable Energy-Based Mini-Grids: The UNIDO Experience; United Nations Industrial Development Organisation: Vienna, Austria, 2017.

9. Panos, E.; Densing, M.; Volkart, K. Access to electricity in the World Energy Council's global energy scenarios: An outlook for developing regions until 2030. Energy Strategy Rev. 2016, 9, 28-49. [CrossRef]

10. Yan, J.; Zhai, Y.; Wijayatunga, P.; Mohamed, A.; Campana, P. Renewable energy integration with mini/micro-grids. Appl. Energy 2017, 201, 241-244. [CrossRef]

11. Mandelli, S.; Barbieri, J.; Mereu, R.; Colombo, E. Off-grid systems for rural electrification in developing countries: Definitions, classification and a comprehensive literature review. Renew. Sustain. Energy Rev. 2016, 58, 1621-1648. [CrossRef]

12. International Energy Agency. The Role of Energy Storage for Mini-Grid Stabilisation, PVPS T11-02; International Energy Agency: Paris, France, 2011.

13. EUEI-PDF. Mini-Grid Policy Toolkit: Policy and Business Frameworks for Successful Mini-Grid Rollouts; European Union Energy Initiative Partnership Dialogue Facility: Eschborn, Germany, 2014.

14. Knuckles, J. Business models for mini-grid electricity in base of the pyramid markets. Energy Sustain. Dev. 2016, 31, 67-82. [CrossRef]

15. Cloke, J.; Mohr, A.; Brown, E. Imagining renewable energy: Towards a Social Energy Systems approach to community renewable energy projects in the Global South. Energy Res. Soc. Sci. 2017, 31, 263-272. [CrossRef]

16. Pedersen, M.B. Deconstructing the concept of renewable energy-based mini-grids for rural electrification in East Africa. WIREs Energy Environ. 2016, 5, 570-587. [CrossRef]

17. Chaurey, A.; Kandpal, T. A techno-economic comparison of rural electrification based on solar home systems and PV microgrids. Energy Policy 2010, 38, 3118-3129. [CrossRef] 
18. Boait, P. Technical aspects of mini-grids for rural electrification. In Mini-Grids for Rural Electrification of Developing Countries; Bhattacharyya, S., Palit, D., Eds.; Springer: London, UK, 2014; pp. 37-61.

19. Boait, P.; Advani, V.; Gammon, R. Estimation of demand diversity and daily demand profile for off-grid electrification in developing countries. Energy Sustain. Dev. 2015, 29, 135-141. [CrossRef]

20. Blum, N.U.; Wakeling, R.S.; Schmidt, T.S. Rural electrification through village grids-Assessing the cost competitiveness of isolated renewable energy technologies in Indonesia. Renew. Sustain. Energy Rev. 2013, 22, 482-496. [CrossRef]

21. ARE. Hybrid Mini-Grids for Rural Electrification: Lessons Learned; Alliance for Rural Electrification: Brussels, Belgium, 2014.

22. Safdar, T. Business Models for Mini-Grids; Technical Report 9; Smart Villages: Cambridge, UK, 2017.

23. Krithika, P.; Palit, D. Participatory business models for off-grid electrification. In Rural Electrification through Decentralised Off-Grid Systems in Developing Countries; Bhattacharyya, S., Ed.; Springer: London, UK, 2013; pp. 187-225.

24. Bhattacharyya, S. Business issues for mini-grid based electrification in developing countries. In Mini-Grids for Rural Electrification of Developing Countries; Bhattacharyya, S., Palit, D., Eds.; Springer: London, UK, 2014; pp. 145-164.

25. Contejean, A.; Verin, L. Making Mini-Grids Work: Productive Uses of Electricity in Tanzania; IIED Working Paper; International Institute for Environment and Development: London, UK, 2017.

26. IRENA. Innovation Outlook: Renewable Mini-Grids; International Renewable Energy Agency: Abu Dhabi, UAE, 2016.

27. Prahalad, C.; Hart, S. The fortune at the Bottom of the Pyramid. Strategy Bus. 2002, 26, 1-14. [CrossRef]

28. Prahalad, C.; Hammond, A. Serving the World's poor, profitably. Harvard Bus. Review. 2002, 80, 48-59.

29. Bhattacharyya, S. Renewable energies and the poor: Niche or nexus? Energy Policy 2006, 34, 659-663. [CrossRef]

30. Cook, P. Infrastructure, rural electrification and developmen. Energy Sustain. Dev. 2011, 15, 304-313. [CrossRef]

31. Ausrod, V.; Sinha, V.; Widding, O. Business model design at the base of the pyramid. J. Clean. Prod. 2017, 162, 982-996. [CrossRef]

32. Alam, M.; Bhattacharyya, S. Are the off-grid customers ready to pay for electricity from the decentralized renewable hybrid mini-girds? A study of willingness to pay in rural Bangladesh. Energy 2017, 139, 433-446.

33. Bhattacharyya, S.; Palit, D. Mini-grid based electrification to enhance electricity access in developing countries: What policies may be required? Energy Policy 2016, 94, 166-178. [CrossRef]

34. Manetsgruber, D.; Wagemann, B.; Kondev, B.; Dziergwa, K. Risk Management for Mini-Grids: A New Approach to Guide Mini-Grid Development; Alliance for Rural Electrification: Brussels, Belgium, 2015.

35. Tenenbaum, B.; Greacen, C.; Siyambalapitiya, T.; Knuckles, J. From the Bottom Up: How Small Power Producers and Mini-Grids Can Deliver Electrification and Renewable Energy in Africa; Directions in Development-Energy and Mining; The World Bank: Washington, DC, USA, 2014.

36. Bhattacharyya, S. To regulate or not to regulate off-grid electricity access in developing countries. Energy Policy 2013, 63, 494-503. [CrossRef]

37. Comello, S.; Reichelstein, S.J.; Sahoo, A.; Schmidt, T. Enabling mini-grid development in India. World Dev. 2017, 93, 94-107. [CrossRef]

38. IRENA. Policies and Regulations for Private Sector Renewable Energy Mini-Grids; International Renewable Energy Agency: Abu Dhabi, UAE, 2016.

39. Doukas, A.; Ballesteros, A. Clean Energy Access in Developing Countries: Perspectives on Policy and Regulation; World Resources Institute: Washington, DC, USA, 2015.

40. Palit, D.; Bandopadhyay, K. Rural electricity access in India in retrospect: A critical rumination. Energy Policy 2017, 109, 109-120. [CrossRef]

41. Attigah, B.; Mayer-Tasch, L. The Impact of Electricity Access on Economic Development-A Literature Review; Deutsche Gesellschaft für Internationale Zusammenarbeit (GIZ) GmbH: Eschborn, Germany, 2013.

42. Banerjee, S.G.; Moreno, A.; Sinton, J.; Primiani, T.; Seong, J. Regulatory Indicators for Sustainable Energy: A Global Scorecard for Policy Makers; The World Bank: Washington, DC, USA, 2016.

43. Solar Energy Foundation. OBIN—Global Off-Grid Business Indicator; Stiftung Solarenergie-Solar Energy Foundation: Merzhausen, Germany, 2014. 
44. IRENA. Accelerating Off-Grid Renewable Energy, IOREC 2014, Key Findings and Recommendations; International Renewable Energy Agency: Abu Dhabi, UAE, 2015.

45. Urmee, T.; Anisuzzaman, M. Social, cultural and political dimensions of off-grid renewable energy programs in developing countries. Renew. Energy 2016, 93, 159-167. [CrossRef]

46. ESMAP. Technical and Economic Assessment of Off-Grid, Mini-Grid and Grid Electrification Technologies; ESMAP Technical Paper 121/07; The World Bank: Washington, DC, USA, 2007.

47. Nouni, M.; Mullick, S.; Kandpal, T. Providing electricity access to remote areas in India: An approach towards identifying potential areas for decentralised electricity supply. Renew. Sustain. Energy Rev. 2008, 12, 1187-1220. [CrossRef]

48. Banerjee, R. Comparison of options for distributed generation in India. Energy Policy 2006, 34, $101-111$. [CrossRef]

49. Bhattacharyya, S. Viability of off-grid electricity supply using rice-husk: A case study of Bangladesh. Biomass Bioenergy 2014, 68, 44-54. [CrossRef]

50. Bhattacharyya, S. Mini-grid based electrification in Bangladesh: Technical configuration and business analysis. Renew. Energy 2015, 75, 745-761. [CrossRef]

51. Ramamurthi, P.; Fernandes, M.; Nielsen, P.; Nunes, C. Utilisation of rice residues for decentralised electricity generation in Ghana: An economic analysis. Energy 2016, 111, 620-629. [CrossRef]

52. Sandwell, P.; Chan, N.; Foster, S.; Nagpal, D.; Emmott, C.; Candelise, C.; Buckle, S.; Ekins-Daukes, N.; Gambhir, A.; Nelson, J. Off-grid solar photovoltaic systems for rural electrification and emissions mitigation in India. Sol. Energy Mater. Sol. Cells 2016, 156, 147-156. [CrossRef]

53. Alam, M.; Bhattacharyya, S. Decentralized Renewable Hybrid Mini-Grids for Sustainable Electrification of the Off-Grid Coastal Areas of Bangladesh. Energies 2016, 9, 268. [CrossRef]

54. Himri, Y.; Stambouli, A.B.; Draoui, B.; Himri, S. Techno-economical study of hybrid power system for a remote village in Algeria. Energy 2008, 33, 1128-1136. [CrossRef]

55. Nandi, S.; Ghosh, H. Prospect of wind-PV-battery hybrid system as an alternative to grid extension in Bangladesh. Energy 2010, 35, 3040-3047. [CrossRef]

56. Dalton, G.; Lockington, D.; Baldock, T. Feasibility analysis of stand-alone renewable energy supply options for a large hotel. Renew. Energy 2008, 33, 1475-1490. [CrossRef]

57. Sen, R.; Bhattacharyya, S. Off-grid electricity generation with renewable energy technologies in India: An application of HOMER. Renew. Energy 2014, 62, 388-398. [CrossRef]

58. Blechinger, P.; Cader, C.; Bertheau, P.; Huyskens, H.; Seguin, R.; Breyer, C. Global analysis of the techno-economic potential of renewable energy hybrid systems on small islands. Energy Policy 2016, 98, 674-687. [CrossRef]

59. Das, B.; Hoque, N.; Mandal, S.; Pal, T.; Raihand, M. A techno-economic feasibility of a stand-alone hybrid power generation for remote area application in Bangladesh. Energy 2017, 134, 775-788. [CrossRef]

60. Chauhan, A.; Saini, R. Techno-economic feasibility study on Integrated Renewable Energy System for an isolated community of India. Renew. Sustain. Energy Rev. 2016, 59, 388-405. [CrossRef]

61. Azimoh, C.; Klintenberg, P.; Wallin, F.; Karlsson, B.; Mbohwa, C. Electricity for development: Mini-grid solution for rural electrification in South Africa. Energy Convers. Manag. 2016, 10, 268-277. [CrossRef]

62. Kolhe, M.; Ranaweera, K.; Gunawardana, A. Techno-economic sizing of off-grid hybrid renewable energy system for rural electrification in Sri Lanka. Sustain. Energy Technol. Assess. 2015, 11, 53-64. [CrossRef]

63. Akpan, U. Technology options for increasing electricity access in areas with low electricity access rate in Nigeria. Socio-Econ. Plan. Sci. 2015, 51, 1-12. [CrossRef]

64. Chakrabarti, S.; Chakrabarti, S. Rural electrification programme with solar energy in remote region-A case study in an island. Energy Policy 2002, 30, 33-42. [CrossRef]

65. Roche, O.; Blanchard, R. Design of a solar energy centre for providing lighting and income-generating activities for off-grid rural communities in Kenya. Renew. Energy 2018, 118, 685-694. [CrossRef]

66. Babatunde, O.; Akinyele, D.; Akinbulire, T.; Oluseyi, P. valuation of grid-independent solar photovoltaic system for primary health centres (PHCs) in developing countries. Renew. Energy Focus 2018, 24, 16-27. [CrossRef]

67. Zubi, G.; Dufo-Lopez, R.; Pasaoglu, G.; Pardo, N. Techno-economic assessment of an off-grid PV system for developing regions to provide electricity for basic domestic needs: A 2020-2040 scenario. Appl. Energy 2016, 176, 309-319. [CrossRef] 
68. Chattopadhyay, D.; Bazilian, M.; Lilienthal, P. More power less cost: Transitioning up the solar energy ladder from home systems to mini-grids. Electr. J. 2015, 28, 41-50. [CrossRef]

69. Graber, S.; Narayanan, T.; Alfaro, J.; Palit, D. Solar microgrids in rural India: Consumers' willingness to pay for attributes of electricity. Energy Sustain. Dev. 2018, 42, 32-43. [CrossRef]

70. Asian Development Bank (ADB). The Future of Mini-Grids: From Low Cost to High Value: Using Demand Driven Design to Maximise Revenue and Impact; CAT Projects; Asian Development Bank: Metro Manila, Philippines, 2013.

71. cKinetics. Financing Decentralised Renewable Energy Mini-grids in India: Opportunities, Gaps and Directions; cKinetics: New Delhi, India, 2013.

72. Domenech, B.; Ferrer-Martí, L.; Pastor, R. Hierarchical methodology to optimize the design of stand-alone electrification systems for rural communities considering technical and social criteria. Renew. Sustain. Energy Rev. 2015, 51, 182-196. [CrossRef]

73. Dufo-López, R.; Bernal-Agustín, J.L.; Yusta-Loyo, J.M.; Domínguez-Navarro, J.A.; Ramírez-Rosado, I.J.; Lujano, J.; Aso, I. Multi-objective optimization minimizing cost and life cycle emissions of stand-alone PV-wind-diesel systems with batteries storage. Appl. Energy 2011, 88, 4033-4041. [CrossRef]

74. Henao, F.; Cherni, JA.; Jaramillo, P.; Dyner, I. A multicriteria approach to sustainable energy supply for the rural poor. Eur. J. Oper. Res. 2012, 218, 801-809. [CrossRef]

75. Bhattacharyya, S.C.; Mishra, A.; Sarangi, G.K. Analytical frameworks and an integrated approach for mini-grid based electrification. In Mini Grids for Rural Electrification of Developing Countries; Bhattacharyya, S., Palit, D., Eds.; Springer International Publishing: Cham, Switzerland, 2014; pp. 95-134.

(C) 2018 by the author. Licensee MDPI, Basel, Switzerland. This article is an open access article distributed under the terms and conditions of the Creative Commons Attribution (CC BY) license (http:/ / creativecommons.org/licenses/by/4.0/). 